Article

\title{
Experimental Analysis of Temperature Influence on Waste Tire Pyrolysis
}

\author{
Zoran Čepić $^{1}$, Višnja Mihajlović ${ }^{2, *}$, Slavko Đurić ${ }^{3}$, Milan Milotić $^{3}$, Milena Stošić $^{1}$, Borivoj Stepanov $^{1}$ \\ and Milana Ilić Mićunović ${ }^{1}$ \\ 1 Faculty of Technical Sciences, University of Novi Sad, 21000 Novi Sad, Serbia; zorancepic@uns.ac.rs (Z.Č.); \\ milenastosic@uns.ac.rs (M.S.); bstep@uns.ac.rs (B.S.); milanai@uns.ac.rs (M.I.M.) \\ 2 Technical Faculty "Mihajlo Pupin", University of Novi Sad, 23000 Zrenjanin, Serbia \\ 3 Faculty of Transport and Traffic Engineering, University of East Sarajevo, 74000 Doboj, Bosnia and Herzegovina; \\ slavko.djuric@sf.ues.rs.ba (S.Đ.); milan.milotic@sf.ues.rs.ba (M.M.) \\ * Correspondence: visnjamihajlovic@uns.ac.rs; Tel.: +381-63-501-577
}

Citation: Čepić, Z.; Mihajlović, V.; Đurić, S.; Milotić, M.; Stošić, M.; Stepanov, B.; Ilić Mićunović, M. Experimental Analysis of Temperature Influence on Waste Tire Pyrolysis. Energies 2021, 14, 5403. https://doi.org/10.3390/en14175403

Academic Editor: Gabriele

Di Giacomo

Received: 11 July 2021

Accepted: 26 August 2021

Published: 30 August 2021

Publisher's Note: MDPI stays neutral with regard to jurisdictional claims in published maps and institutional affiliations.

Copyright: (c) 2021 by the authors. Licensee MDPI, Basel, Switzerland. This article is an open access article distributed under the terms and conditions of the Creative Commons Attribution (CC BY) license (https:// creativecommons.org/licenses/by/ $4.0 /)$.

\begin{abstract}
Pyrolysis is an optimal thermochemical process for obtaining valuable products (char, oil, and gas) from waste tires. The preliminary research was done on the three groups of samples acquired by cutting the same waste tire of a passenger vehicle into cylindrical granules with a base diameter of 3, 7, and $11 \mathrm{~mm}$. Each batch weighed $10 \mathrm{~g}$. The heating rate was $14{ }^{\circ} \mathrm{C} / \mathrm{min}$, and the final pyrolysis temperature was $750{ }^{\circ} \mathrm{C}$, with $90 \mathrm{~s}$ residence time. After the pyrolysis product yields were determined for all of the three sample groups, further research was performed only on $3 \mathrm{~mm}$ granules, with the same heating rate, but with altered final pyrolytic temperatures $(400,450,500$, $550,600,650,700$, and $750{ }^{\circ} \mathrm{C}$ ). The results of this study show that thermochemical decomposition of the waste tire sample takes place in the temperature range of $200-500{ }^{\circ} \mathrm{C}$, with three distinct phases of degradation. The highest yield of the pyrolytic oil was achieved at a temperature of $500{ }^{\circ} \mathrm{C}$, but further heating of volatile matters reduced the oil yield, and simultaneously increased the yield of gas, due to the existence of secondary cracking reactions. The analysis of pyrolytic oil and char showed that these products can be used as fuel.
\end{abstract}

Keywords: waste tire; pyrolysis; batch reactor; temperature; fuel

\section{Introduction}

There is a growing concern about waste tires since their annual increase is approximately 17 million tons on the global scale [1]. As some estimations show, this increment of tire waste could be up to 1.2 billion tons annually, by the end of 2030s [2]. This represents a potentially large environmental problem because of the vastly resilient nature of rubber against physical, chemical, and biological waste treatments. Rubber tires are designed to endure rough mechanical and weather conditions while remaining functional and undamaged among extreme settings, including the presence of microorganisms. This capacity of heavy resistance is one of the main reasons why rubber is difficult to reutilize or process [3].

Tires are usually composed of natural rubber (NR) (20-25\%), styrene-butadiene rubber (SBR) (30-50\%), butyl rubber (BR) (up to 30\%), carbon black (CB) (around 30\%), sulphur $(1-2.5 \%)$, and small quantities of organic and inorganic additives [4,5]. Due to the fact that rubber tires contain a significant amount of carbon black, and have a heating value greater than coal (approximately $35 \mathrm{MJ} / \mathrm{kg}$ ), discovering a way to benefit from their great energetic and raw material potential became the objective of many alternative fuel studies [6].

Until recently, two principal approaches to disposition of waste tires were landfilling and incineration. However, since 1999, landfilling of this kind of waste has been banned in the EU [7]. Additionally, incineration has not been shown to be an acceptable method to treat waste tires due to toxic gasses emission (volatile organic compounds-VOC, CO, $\mathrm{CO}_{2}$, dioxins, dioxin-like compounds,) and particulates [8]. In that respect, pyrolysis is 
considered to be one of the optimal approaches of decreasing, if not solving, waste tire concern, since this disposal method allows for the retrieval of valuable products from used tires: pyrolytic oil, which can be used as fuel, gas with high caloric value, which can further fuel the pyrolytic process, and a residual char (solid residue) usable as a smokeless fuel, carbon black, or activated charcoal [4,9].

The key process parameter that can be varied in pyrolysis is temperature [10-15]. Temperature affects the way the pyrolysis process takes place, the occurrence of certain reactions, and consequently, the amount and the composition of pyrolysis products. Several studies $[11,13,16-18]$ have indicated that $500{ }^{\circ} \mathrm{C}$ is the optimum temperature, at atmospheric pressure, for achieving total tire conversion. At temperatures below $500{ }^{\circ} \mathrm{C}$, tire compounds such as NR, SBR, and BR still remain in the pyrolytic solid residue. Conversely, an increase in the temperature could support an increase in the gas fraction yield on account of the liquid fraction yield, which is conditioned by the occurrence of secondary cracking reactions. Although the influence of the temperature on the yield of pyrolysis products has been analyzed in many papers, a relatively small number of papers indicate an increase in non-condensable gases with a decrease in oil yield, i.e., the occurrence of secondary reactions [4,19-22]. In addition, there is a large difference in the obtained results, which imposes the need for more experimental research in this field.

The main objective of this experiment was to determine the influence of temperature on yield and composition of pyrolysis products, with other process parameters remaining unchanged.

\section{Materials and Methods}

\subsection{Description of the Experimental Plant}

A schematic representation of the laboratory plant setting used for the pyrolysis of waste tires is given in Figure 1, together with the depiction of measuring points (M.P.). The specific construction of furnace and reactor allowed the examination of batch (noncontinuous) pyrolysis, combustion, and gasification processes with maximum reaction temperature of $750{ }^{\circ} \mathrm{C}$. The electric furnace was $410 \mathrm{~mm}$ high, with a $320 \mathrm{~mm}$ outer diameter and a $150 \mathrm{~mm}$ inner diameter, and coated with insulating material (rock mineral wool). Three separately controlled electric heaters with a total power of $5.4 \mathrm{~kW}$ surrounded the furnace and heated the reactor vessel with the tested waste tire sample to the desired temperature. The reactor vessel was $200 \mathrm{~mm}$ high and had an inner diameter of $72 \mathrm{~mm}$.

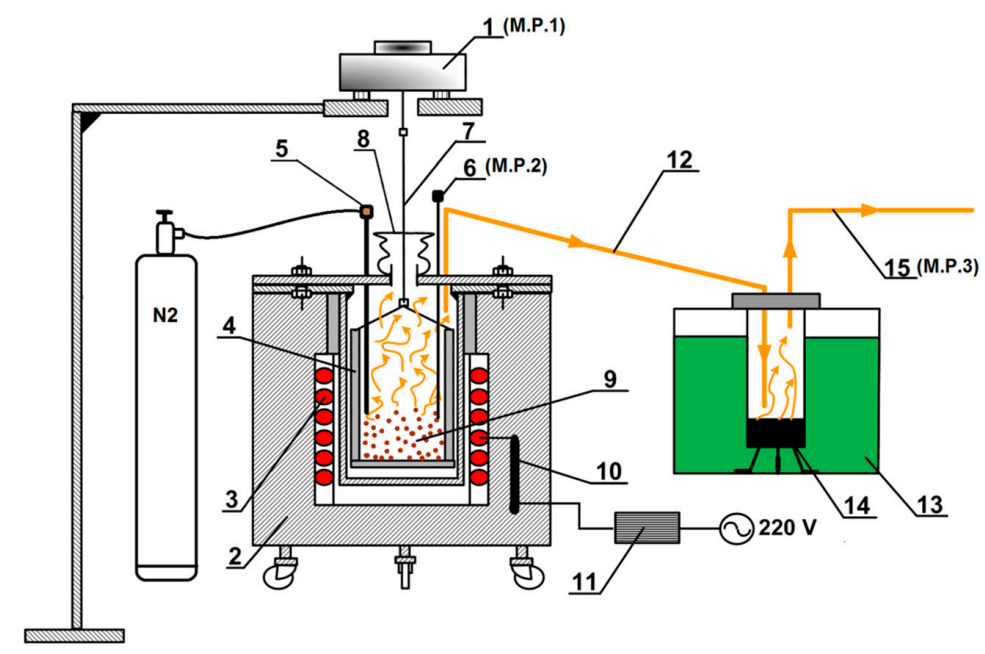

Figure 1. Scheme of a laboratory plant for pyrolysis [23]. 1-digital scale (M.P.1), 2-pyrolysis reactor, 3-electric heaters, 4 -reactor vessel, 5- $\mathrm{N}_{2}$ cylinder with flowmeter, 6-thermocouple (M.P.2), 7-connection between scale and reactor vessel, 8-flexible teflon sheath, 9-tested sample of waste tires, 10-temperature regulator sensor, 11-temperature regulator, 12-volatiles outlet, 13-cooler, 14-pyrolytic oil, 15-pyrolytic gas sampling (M.P.3). 
The laboratory plant setting had three measuring points (M.P.) and they consisted of a digital scale Mettler P1000 for measuring the change of the sample mass (M.P.1), a digital thermometer, Testo 925 , with a probe type $\mathrm{K}(\mathrm{NiCr}-\mathrm{Ni})$ for measuring the temperature in the reactor vessel (M.P.2), and a gas analyzer, G 750 Polytector II, used to measure the volume fraction of $\mathrm{CH}_{4}, \mathrm{H}_{2}, \mathrm{CO}$, and $\mathrm{CO}_{2}$ at the plant outlet (M.P.3). The choice of measuring points was made in such a way that it accurately depicts the state of the measured parameters during the pyrolysis process.

\subsection{Sample Preparation}

The experiment was done on three groups of samples obtained from the waste tire of a passenger vehicle. Samples were acquired by cutting the same waste tire into three different sized cylindrical granules. The first waste tire sample (WTS1) consisted of granules with a base diameter of $3 \mathrm{~mm}$, the second waste tire sample (WTS2) included granules with base diameter of $7 \mathrm{~mm}$, and the third waste tire sample (WTS3) contained granules with a base diameter of $11 \mathrm{~mm}$. Granules in all samples had the same height of $6 \mathrm{~mm}$. Each sample weighed $10 \mathrm{~g}$ and did not contain wire components of the tires. WTS1 contained 334.4 granules with a total surface area of $236.4 \mathrm{~cm}^{2}$. WTS2 contained 61.4 granules with a total surface area of $128.3 \mathrm{~cm}^{2}$. WTS3 contained 24.9 granules with a total surface area of $98.9 \mathrm{~cm}^{2}$. As each batch weighed exactly $10 \mathrm{~g}$, one granule in each batch was shorter as needed.

\subsection{Experimental Procedure}

Based on the previous research by the authors, presented in [24], $14^{\circ} \mathrm{C} / \mathrm{min}$ was defined as the heating rate. The final pyrolysis temperatures were 400, 450, 500, 550, 600, 650,700 , and $750{ }^{\circ} \mathrm{C}$. Residence time was the same in all experiments, $90 \mathrm{~s}$, and the carrier gas $\left(\mathrm{N}_{2}\right)$ flow rate was $0.54 \mathrm{~L} / \mathrm{min}$. During the heating process, the change in sample mass (M.P.1) and the temperature in the reaction vessel (M.P.2) were measured simultaneously. The measured data were used to plot the TG and DTG curves. Before the start of the measurements, test measurements were performed and it was determined that the defined flow rate of carrier gas does not affect the accuracy of the measurements. Volatile matters released during the heating process were taken to a cooler, where condensable compounds (i.e., pyrolytic oil) are condensed, and non-condensable gases (i.e., pyrolytic gas) were further taken to a gas analyzer (M.P.3). At the end of the pyrolysis process, the mass of separated pyrolytic oil was measured. Each measurement was repeated three times, and before each measurement the reactor was purged by the flow of $\mathrm{N}_{2}$ gas of $5 \mathrm{~L} / \mathrm{min}$ for $5 \mathrm{~min}$ to remove the air. Pyrolytic oils belonging to the same measurement group (measurement group implies three measurements of the same sample type at the same final temperature, e.g., three times WTS1 at $400{ }^{\circ} \mathrm{C}$ ) are mixed and well homogenized before determining the elemental composition and physical properties. For elemental composition and gross calorific value, LECO CHN-600, LECO SC-132 automatic determiners, and LECO AC-300 automatic calorimetric bombs were used. Density, viscosity, flash point, pour point, and GCV were the determined physical properties, using the following standard methods: ASTM D189, ASTM D445, ASTM D92, ASTM D97, and ASTM D240, respectively.

\section{Results and Discussion}

\subsection{Proximate and Ultimate Analysis of Samples}

Proximate and ultimate analysis of the samples used in the experiment is given in Table 1. The obtained values correspond to the values stated by other authors, which confirms that waste tires are a suitable material for pyrolysis $[12,19,25,26]$. Furthermore, the gross calorific value (GCV) of the tested samples was about $32 \mathrm{MJ} / \mathrm{kg}$, which is significantly more compared to the calorific value of biomass, or to the calorific value of most coals [27-29], which, from the energy aspect, makes waste tires a respectable energy source whose possibilities are worth exploring further. 
Table 1. Proximate analysis, ultimate analysis and calorific value of waste tire.

\begin{tabular}{ccccccccccc}
\hline & \multicolumn{3}{c}{ Proximate Analysis } & & \multicolumn{3}{c}{ Ultimate Analysis } & \multicolumn{3}{c}{ Calorific Value } \\
\hline Moisture & Ash & Volatile Matter & Fixed Carbon & C & H & O & N & S & GCV \\
\hline wt. $\%$ & wt. $\%$ & wt. $\%$ & wt. $\%$ & wt. $\%$ & wt. $\%$ & wt. $\%$ & wt. $\%$ & wt. $\%$ & MJ $/ \mathbf{k g}$ \\
\hline 0.3 & 13.2 & 61.0 & 25.5 & 72.3 & 5.8 & 6.1 & 0.4 & 1.9 & 32.12 \\
\hline
\end{tabular}

\subsection{The Influence of the Waste Tire Granules Size on the Yield of Pyrolysis Products}

The influence of the waste tire granules' size on the yield of solid, liquid, and gaseous pyrolysis products is shown in Figure 2. All samples were heated at the same rate, $14{ }^{\circ} \mathrm{C} / \mathrm{min}$, to a temperature of $750{ }^{\circ} \mathrm{C}$. It is noticeable that with the increase of the tested samples' granule size, the yield of solid residue (char) increases slightly from $39.9 \%$ for WTS1 to $41.3 \%$ for WTS3. Although small, the change in the char yield could mean that the rate of thermal decomposition may decrease with increasing granule size. This is due to the smaller heat exchange area, i.e., the slower heat transfer to the center of the larger granules, because the tires have very low thermal conductivity $[4,20,21,30]$. The size of the sample granules also has an impact on the yield of the liquid and gaseous phases of pyrolysis. For WTS1, the yield of gas and oil was 33.5\% and 26.6\%, respectively. For WTS2 and WTS3, the yield of gas decreases to $22.7 \%$ and $22.6 \%$, while the yield of oil versus gas increases to $36.4 \%$ and 36.1 , respectively. Such changes in pyrolysis gas and liquid phase yields could be explained as follows. The sample consisting of the smallest granules (WTS1) had the largest surface area for heat exchange, and easier and faster heat transfer was enabled over the entire volume of the granules, which led to rapid thermal decomposition of the samples. Moreover, the high gas yield is not only a consequence of the primary decomposition of the samples, but also of the secondary cracking reactions of pyrolytic oil, which will be discussed below. This is not the case for samples with larger granules (WTS2 and WTS3), where a significant decrease in gas yield and increase in oil yield can be observed. This is due to slower pyrolysis or insufficient time at a high temperature for secondary reactions. These findings clearly show that bigger granules need longer reaction times than smaller ones to reach the same pyrolysis conversion grade $[6,21]$. WTS1 was selected for further research, because under the mentioned experimental conditions, only in this case has the increase of temperature from 500 to $750{ }^{\circ} \mathrm{C}$ led to the appearance of secondary cracking reactions of pyrolytic oil.

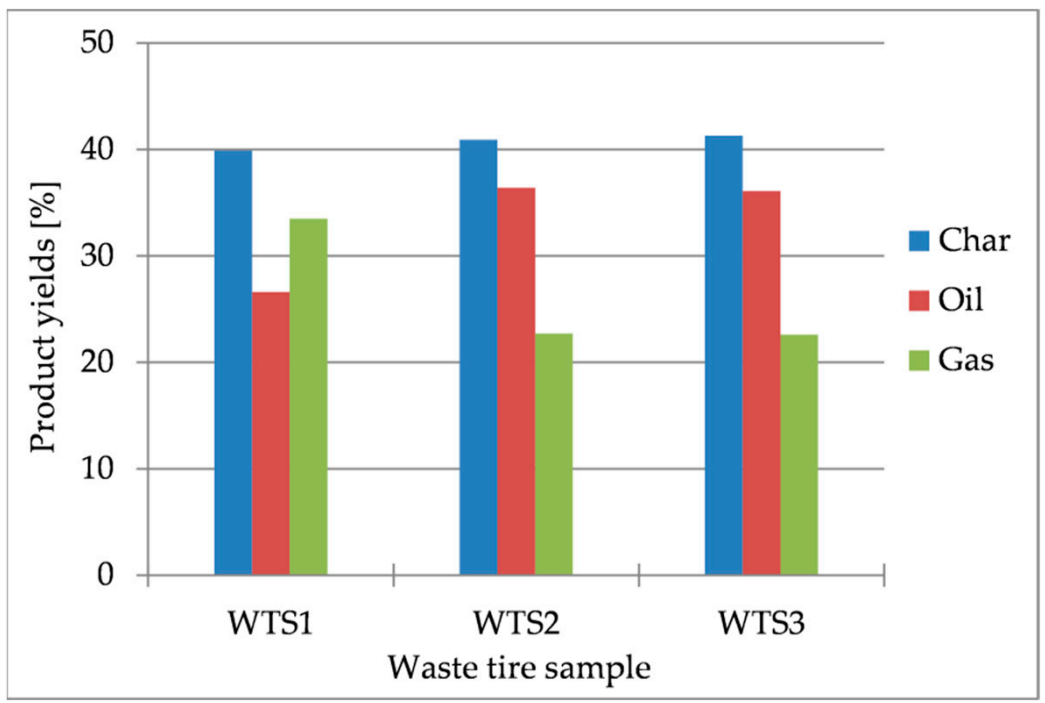

Figure 2. The share of pyrolysis products in relation to the size of the granules. 


\subsection{Thermogravimetry and Differential Thermogravimetry}

Thermogravimetry (TG) and differential thermogravimetry (DTG) are very powerful and effective techniques for fuel combustion profile determination. As already mentioned, tires have very low thermal conductivity, so TG should be employed at a heating rate up to $20^{\circ} \mathrm{C} / \mathrm{min}$, due to the fact that the real temperature of the sample may be different from the measured temperature of the sample for higher heating rates [31]. Figure 3 shows TG and DTG curves for waste tire samples. The TG curve shows that the thermal decomposition of the sample takes place in the temperature range $200-500{ }^{\circ} \mathrm{C}$, while the DTG curve shows the existence of three phases of thermal decomposition of the sample. The first phase takes place in the temperature range of $200-350{ }^{\circ} \mathrm{C}$ and corresponds to the devolatilization of additives such as stearic acid (plasticizer), extender oils, etc. [32,33]. The second phase of thermal decomposition takes place in the temperature range $350-420^{\circ} \mathrm{C}$ and corresponds to the decomposition of NR [32,33], while the third takes place in the temperature range $420-500{ }^{\circ} \mathrm{C}$ and corresponds to the decomposition of SBR and BR [32,33]. There was no change in the mass of the solid sample residue in the temperature range of $500-750{ }^{\circ} \mathrm{C}$.

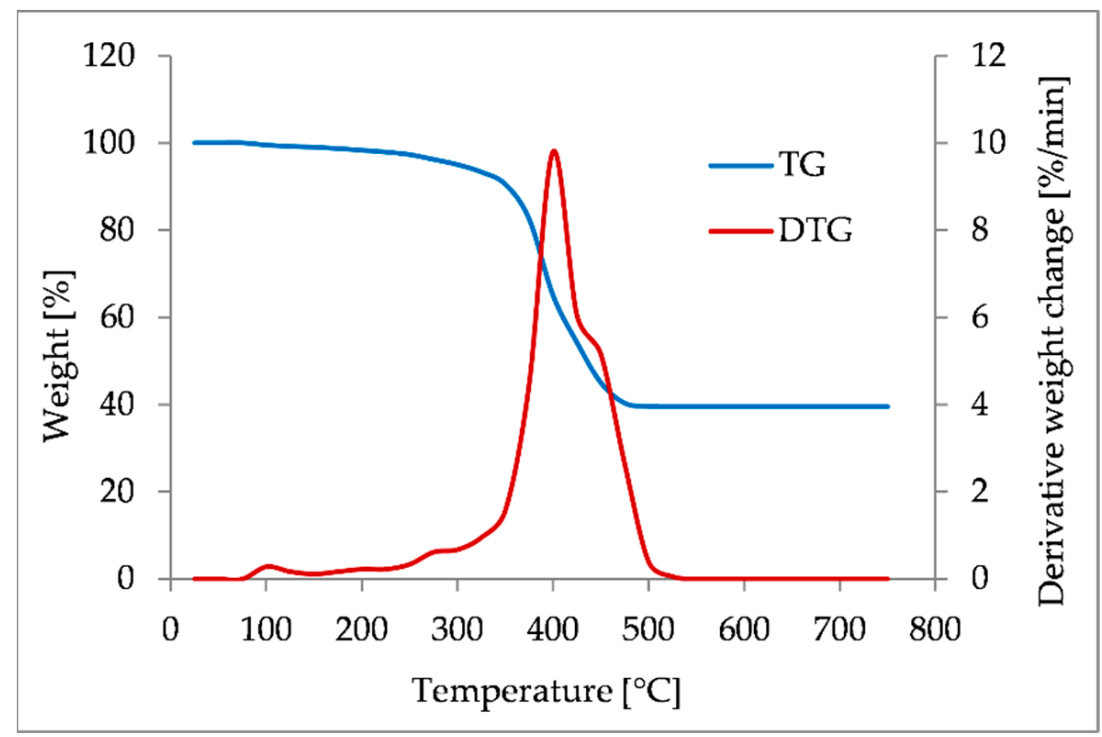

Figure 3. TG and DTG curves of the waste tire.

\subsection{Pyrolysis Yields}

Pyrolysis is a thermochemical process, occurring at an elevated temperature and inert atmosphere, in which the waste tire is transformed into a solid residue rich in carbon (char), with the release of volatiles (oil + gas), which can be represented by the following reaction:

$$
\text { Waste tire } \rightarrow \text { Char }+ \text { Oil + Gases }\left(\mathrm{CO}, \mathrm{CO}_{2}, \mathrm{H}_{2}, \mathrm{CH}_{4}, \mathrm{C}_{\mathrm{m}} \mathrm{H}_{\mathrm{n}}\right)
$$

Table 2 shows the solid, liquid, and gas yields (wt.\%) that are acquired in the tire pyrolysis tests carried out at $400-750{ }^{\circ} \mathrm{C}$. Solid and liquid pyrolysis yields were established by measuring the volume of each fraction. The gas fraction yields were found as a difference.

After the thermal decomposition is done, variations on the char yield are not expected when pyrolysis temperature increases. Therefore, the total amount of char needs to be in relation with the sum of the original $\mathrm{CB}$ and the ash content. The amount of char, however, can be higher than this anticipated value since aromatics tend to adsorb on the surface of the char $[4,6,34]$. The amount of char can also be lower than the expected value in conditions when the oxygen is present in the carrier gas due to the occurrence of gasification reactions at increased temperatures $[6,35,36]$. 
Table 2. The effects of temperature on pyrolysis products yield.

\begin{tabular}{cccc}
\hline Temperature & Char & Oil & Gas \\
\hline${ }^{\circ} \mathbf{C}$ & wt. $\%$ & wt. $\%$ & wt. $\%$ \\
\hline 400 & 58.7 & 27.0 & 14.3 \\
450 & 45.8 & 38.4 & 15.8 \\
500 & 39.9 & 43.6 & 16.5 \\
550 & 40.0 & 42.6 & 17.4 \\
600 & 39.9 & 40.0 & 20.1 \\
650 & 40.0 & 37.3 & 22.7 \\
700 & 39.9 & 32.1 & 28.0 \\
750 & 39.9 & 26.6 & 33.5 \\
\hline
\end{tabular}

It is obvious from the Table 2 that product yields depend on the temperature. At the temperature of $400-500{ }^{\circ} \mathrm{C}$, pyrolysis was still partial and incomplete, as char yield was higher than the values obtained from the TG analysis. This is supported by the fact that the solid residue after pyrolysis at $400{ }^{\circ} \mathrm{C}$ was rubbery and sticky. On the other hand, char yields at $500-750{ }^{\circ} \mathrm{C}$ were almost identical, indicating that the thermal decomposition of the sample was completed at approximately $500{ }^{\circ} \mathrm{C}$. When it comes to pyrolytic oil, with the increase of the final pyrolytic temperature, the oil yield simultaneously increases and reaches a maximum value of $43.6 \%$ at about $500{ }^{\circ} \mathrm{C}$, after which it begins to decrease, and at $750{ }^{\circ} \mathrm{C}$ it declines to the value of $26.6 \%$. In the case of pyrolytic gas, a slight increase in yield is observed for the final pyrolysis at the temperature of $400-500{ }^{\circ} \mathrm{C}$. However, with an increase in the final pyrolytic temperature from 500 to $750{ }^{\circ} \mathrm{C}$ the gas yield is more significant, and at $750{ }^{\circ} \mathrm{C}$ it reaches a maximum value of $33.5 \%$. This yield ratio of pyrolytic oil and gas is the result of the secondary cracking reactions that occur at high temperatures to form non-condensable gases and therefore increase the gas yield and at the same time reduce the oil yield. These reactions could be expressed as:

$$
\begin{gathered}
\text { Oil } \rightarrow \text { Heavy hydrocarbons }+ \text { Light hydrocarbons }+\mathrm{CO}+\mathrm{CO}_{2}+\mathrm{H}_{2} \\
\text { Heavy hydrocarbons } \rightarrow \text { Light hydrocarbons }+\mathrm{CH}_{4}+\mathrm{H}_{2} \\
\text { Light hydrocarbons } \rightarrow \mathrm{CH}_{4}+\mathrm{H}_{2}
\end{gathered}
$$

Although the influence of the temperature on the yield of pyrolysis products has been analyzed in many papers, a relatively small number of papers indicate an increase in non-condensable gases with a decrease in oil yield, i.e., the occurrence of secondary reactions [4,19-22].

\subsection{Pyrolysis Products}

\subsubsection{Char}

In the case of waste tire pyrolysis, the carbon in the solid residue comes from rubber and $\mathrm{CB}$, which are the two most common raw materials in the production of tires. The composition of the char, besides the composition of the waste tire, depends on the conditions under which the pyrolytic process takes place $[37,38]$.

Table 3 gives an elementary analysis of the solid residue obtained at 500 and $750{ }^{\circ} \mathrm{C}$. At both temperatures, the solid residues had retained approximately the same form as the samples before the pyrolysis began, and were easily crushed into a black powder. The most important detail regarding tire pyrolytic residues is their pronounced share of ash $(\sim 13 \%)$, compared to commercial carbon blacks where ash residue doesn't exceed $0.5 \%$. The ash from the pyrolytic residues originates from the inorganic content (steel excluded) of the tire. Even though char from the tire pyrolysis has much higher ash content than commercial carbon blacks, it can still be used as an alternative material in the preparation of rubber parts like footwear, conveyor belts, dock fenders, etc. Further possible uses for tire pyrolysis solid residue involve activated carbon, ink pigments or solid fuel. Observed 
from the energy aspect, char has excellent potential to be used as a solid fuel, keeping in mind that the share of carbon is about $82 \%$, and GCV about $29 \mathrm{MJ} / \mathrm{kg}$. However, an ash content of $13 \%$ and sulfur content of over $2 \%$ can be an environmental problem.

Table 3. Ultimate analyses, ash content, and gross calorific value (GCV) of the char obtained in waste tire pyrolysis.

\begin{tabular}{cccccccc}
\hline Temperature & $\mathbf{C}$ & H & N & S & O & Ash & GCV \\
\hline${ }^{\circ} \mathbf{C}$ & wt. $\%$ & wt. $\%$ & wt. $\%$ & wt. $\%$ & wt. $\%$ & wt. $\%$ & MJ $/ \mathbf{k g}$ \\
\hline 500 & 81.9 & 0.9 & 0.4 & 2.2 & 1.8 & 12.8 & 28.5 \\
750 & 82.3 & 0.4 & 0.4 & 2.4 & 1.1 & 13.4 & 29.1 \\
\hline
\end{tabular}

\subsubsection{Pyrolytic Gas}

Gaseous pyrolysis products of waste tires predominantly contain $\mathrm{H}_{2}, \mathrm{CO}, \mathrm{CO}_{2}, \mathrm{CH}_{4}$ $\mathrm{C}_{2} \mathrm{H}_{6}$, and $\mathrm{C}_{4} \mathrm{H}_{6}[12,30,39]$. Table 4 presents the composition of the gases obtained in tire pyrolysis at $400-750{ }^{\circ} \mathrm{C}$. In regard to methane and hydrogen, there is a noticeable upsurge in the share of these gases at temperatures higher than $500{ }^{\circ} \mathrm{C}$. This is due to the fact that light hydrocarbons can be formed in two possible ways: by direct degradation of polymeric compounds (SBR and BR), and in secondary cracking reactions that occur if these products are exposed to temperatures higher than $500{ }^{\circ} \mathrm{C}$ long enough. Compared to $\mathrm{SBR}$, which is an aromatic compound, the degradation products of polymeric compounds contain shorter aliphatic chains that in reactions like thermal cracking, repolymerization, or recondensation, release light gases such as methane and hydrogen [18]. In terms of carbon monoxide and carbon dioxide, they are oxidation products of organic compounds contained in the tire, such as stearic acid, extender oils, etc., and can also be the product of thermal decomposition of inorganic components, such as $\mathrm{CaCO}_{3}$ and metal oxides [11,40]. As shown in Table 4, these mechanisms of $\mathrm{CO}_{2}$ generation are significantly more pronounced at temperatures from 400 to $500{ }^{\circ} \mathrm{C}$ than from 500 to $750{ }^{\circ} \mathrm{C}$, while the share of $\mathrm{CO}$ at all temperatures was above the measuring range of the device (>0.1 vol.\%).

Table 4. Pyrolysis gas composition [vol.\%].

\begin{tabular}{ccccccccc}
\hline \multirow{2}{*}{ Pyrolysis Gas } & \multicolumn{7}{c}{ Pyrolysis Temperature $\left[{ }^{\circ} \mathrm{C}\right]$} \\
\cline { 2 - 9 } & $\mathbf{4 0 0}$ & $\mathbf{4 5 0}$ & $\mathbf{5 0 0}$ & $\mathbf{5 5 0}$ & $\mathbf{6 0 0}$ & $\mathbf{6 5 0}$ & $\mathbf{7 0 0}$ & $\mathbf{7 5 0}$ \\
\hline $\mathrm{CH}_{4}$ & 2.6 & 4.5 & 12.9 & 15.3 & 19.0 & 20.2 & 22.5 & 23.2 \\
$\mathrm{H}_{2}$ & 3.4 & 3.8 & $>4$ & $>4$ & $>4$ & $>4$ & $>4$ & $>4$ \\
$\mathrm{CO}_{2}$ & 14.0 & 10.5 & 9.0 & 9.1 & 8.5 & 8.3 & 7.9 & 7.1 \\
\hline
\end{tabular}

1 exceeds the measuring range.

\subsubsection{Pyrolytic Oil}

Pyrolytic oil obtained from pyrolysis of waste automotive tires is dark-brown liquid, which looks like a petroleum fraction. Since the most common polymer component of automotive tires is styrene-butadiene, which has both an aromatic (styrene) and aliphatic (butadiene) structure, pyrolytic oil is a mixture of aromatic and aliphatic compounds [41]. There was no phase separation in the pyrolytic oil obtained in experiments. The pyrolytic oil was characterized in terms of both fuel properties and elemental compositions for two final pyrolysis temperatures, $500{ }^{\circ} \mathrm{C}$ and $750{ }^{\circ} \mathrm{C}$, and the results were compared with commercial No. 2 diesel and light fuel oil, which is shown in Table 5.

The density of pyrolytic oil obtained at $500{ }^{\circ} \mathrm{C}$ and $750{ }^{\circ} \mathrm{C}$ was 937 and $959 \mathrm{~kg} / \mathrm{m}^{3}$, respectively, and in both cases was higher in density than commercial diesel and light fuel oil. Since high density is dependent on the molecular weight of the fuel molecules [19], this implies that pyrolytic oil has heavier molecules than commercial diesel and light fuel oil. The viscosity of pyrolytic oil was $4.7 \mathrm{cSt}$ for oil obtained at $500{ }^{\circ} \mathrm{C}$, and $5.0 \mathrm{cSt}$ for oil obtained at $750{ }^{\circ} \mathrm{C}$. The viscosity in both cases was slightly higher than the viscosity of commercial diesel, but significantly lower than the viscosity of light fuel oil. Relatively 
low viscosity of the pyrolytic oil is a favorable feature in the handling, transporting, and the usage of the pyrolytic oil as a fuel. Flash point is the temperature at which the fuel begins to evolve vapors in sufficient quantity to form a flammable mixture with air. In other words, temperature is an indirect measure of volatility of the liquid fuel. The flash points of pyrolytic oil obtained at $500{ }^{\circ} \mathrm{C}$ and $750{ }^{\circ} \mathrm{C}$ were $\leq 31^{\circ} \mathrm{C}$ and $\leq 48{ }^{\circ} \mathrm{C}$, respectively, and the obtained values are relatively low compared to commercial diesel $\left(55^{\circ} \mathrm{C}\right)$ and light fuel oil $\left(79^{\circ} \mathrm{C}\right)$. The low flash points of the pyrolytic oil (especially the oil obtained at $500{ }^{\circ} \mathrm{C}$ ) are not surprising since the pyrolytic oil represents an unrefined liquid that is a mixture of components with a wide distillation range. In addition, the difference in the value of the flash point for these two pyrolytic oils confirms that at higher final pyrolysis temperatures, light gases, such as methane and hydrogen, were released, which has already been discussed. The pour points of pyrolytic oil are significantly higher compared to diesel fuel, but this would not be a problem in the case of its use in hot regions. Gross calorific value is 42.4 and $41.1 \mathrm{MJ} / \mathrm{kg}$ for pyrolytic oil obtained at $500{ }^{\circ} \mathrm{C}$ and $750{ }^{\circ} \mathrm{C}$, respectively, which is slightly lower than GCV of commercial diesel and light fuel oil, but still very respectable.

Table 5. Characteristics of pyrolytic oil compared to diesel fuel and fuel oil.

\begin{tabular}{ccccc}
\hline Analyses & $\begin{array}{c}\text { Pyrolytic Oil } \\
{\left[\mathbf{5 0 0}{ }^{\circ} \mathbf{C}\right]}\end{array}$ & $\begin{array}{c}\text { Pyrolytic Oil } \\
{\left[\mathbf{7 5 0}{ }^{\circ} \mathbf{C}\right]}\end{array}$ & $\begin{array}{c}\text { Commercial } \\
\text { No. 2 Diesel }\end{array}$ & Light Fuel Oil \\
\hline Elemental [wt.\%] & 85.4 & & & - \\
$\mathrm{C}$ & 10.1 & 87.5 & - & - \\
$\mathrm{H}$ & 1.2 & 7.6 & 0.001 & - \\
$\mathrm{S}$ & 0.5 & 1.3 & - & - \\
$\mathrm{N}$ & 2.8 & 0.7 & - & - \\
$\mathrm{O}$ & 1.42 & 2.9 & - & 890 \\
$\mathrm{H} / \mathrm{C}$ ratio & 937 & 1.04 & $820-860$ & 21 \\
Density $\left[\mathrm{kg} / \mathrm{m}^{3}\right]$ & 4.7 & 959 & $2.0-4.5$ & 79 \\
Viscosity ${ }^{1}[\mathrm{cSt}]$ & 31 & 5.0 & $>55$ & - \\
Flash point $\left[{ }^{\circ} \mathrm{C}\right]$ & -11 & 48 & -40 to -30 & 44.8 \\
Pour point $\left[{ }^{\circ} \mathrm{C}\right]$ & 42.4 & -6 & $44-46$ & \\
GCV $[\mathrm{MJ} / \mathrm{kg}]$ & & 41.1 & & \\
\hline
\end{tabular}

${ }^{1}$ At a temperature of $40^{\circ} \mathrm{C}$.

When it comes to chemical (elemental) composition, it is noticeable that the pyrolytic oil obtained at the final pyrolysis temperature of $750{ }^{\circ} \mathrm{C}$ has $2.5 \%$ lower hydrogen content than the oil obtained at $500{ }^{\circ} \mathrm{C}$. This is due to the effect of the volatile fraction cracking reactions, which has already been discussed. As a result, the $\mathrm{H} / \mathrm{C}$ molar ratio for pyrolytic oil obtained at $750{ }^{\circ} \mathrm{C}$ is significantly lower. Pyrolytic oil also contains just over $1 \%$ sulfur $(\sim 1.2 \%)$, which is significantly more than the EU limit value for Commercial No. 2 diesel (10 ppm), but below the limit value for light fuel oil (1.4\%). Considering density, viscosity, flash point, pour point, and sulfur content, pyrolytic oil could not be an alternative to commercial diesel without prior processing. On the other hand, low viscosity and sulfur content make it more suitable fuel for industrial furnaces and boilers, for direct use or blended with fuel oil.

\section{Conclusions}

Waste tires are a serious environmental issue given their quantity and resistance to physical, chemical, and other types of treatment. On the other hand, their composition and caloric value make them a significant source of energy and raw materials. As the combustion of waste tires is not environmentally acceptable, pyrolysis is recognized as the optimal process for obtaining valuable products (char, oil, and gas). In the pyrolysis process, one of the key parameters is temperature. Temperature affects the way the pyrolysis process takes place, i.e., on the participation of certain types of reactions and consequently the quantity and composition of pyrolysis products. The aim of this study was to determine the influence of the temperature, while other process parameters remain unchanged.

The following conclusions were obtained: 
- TG and DTG analyses showed that the thermal decomposition of the samples took place in three phases in the temperature range between 200 and $500^{\circ} \mathrm{C}$. The first phase corresponds to the devolatilization of the additive $\left(200-350{ }^{\circ} \mathrm{C}\right)$, the second phase to the thermal decomposition of NR $\left(350-420^{\circ} \mathrm{C}\right)$, and to the third phase to the thermal decomposition of SBR and BR $\left(420-500^{\circ} \mathrm{C}\right)$. There was no change in the mass of the solid residue in the temperature range of $500-750^{\circ} \mathrm{C}$;

- As the size of the granules increases, the rate of thermal decomposition decreases due to the smaller heat exchange area, i.e., the slower heat transfer to the center of the larger granules. For the smallest granules (WTS1), the high gas yield is not only a consequence of the primary decomposition of the samples, but also of the secondary cracking reactions of the pyrolytic oil. This was not the case for WTS2 and WTS3, due to the slower pyrolysis and insufficient time at high temperature for secondary reactions, so the yield of oil was significantly higher than the yield of gas;

- Solid residues obtained at temperatures below $500{ }^{\circ} \mathrm{C}$ were rubbery and sticky and had higher masses than those obtained at temperatures higher than $500{ }^{\circ} \mathrm{C}$, indicating incomplete thermal decomposition, while solid residues obtained at temperatures between 500 and $750{ }^{\circ} \mathrm{C}$ were of the same mass and shape, which indicates that the thermal decomposition of the solid residue is completed already at $500{ }^{\circ} \mathrm{C}$. The chemical composition of solid residues obtained at temperatures of 500 and $750{ }^{\circ} \mathrm{C}$ was very similar, and the ash content was about $13 \%$, which is significantly above the maximum commercial CB ash content. The GCV of the solid residue was about $29 \mathrm{MJ} / \mathrm{kg}$, but it should be noted that a sulphur content of over $2 \%$ may be a limiting factor for fuel use;

- The highest yield of pyrolytic oil $(43.6 \%)$ was achieved at about $500{ }^{\circ} \mathrm{C}$. With a further increase in temperature, the oil yield constantly decreased, while the gas yield simultaneously increased and reached a maximum value $(33.5 \%)$ at $750{ }^{\circ} \mathrm{C}$. This ratio of pyrolytic oil and gas yield, as well as the constant increase of methane content in pyrolytic gas at temperatures of $500-750{ }^{\circ} \mathrm{C}$, indicates the existence of secondary cracking reactions in which, due to the high temperature, condensable hydrocarbons decompose into non-condensable ones. Besides that, pyrolytic oil obtained at a final pyrolysis temperature of $750{ }^{\circ} \mathrm{C}$ has lower hydrogen content for $2.5 \%$ than oil obtained at $500{ }^{\circ} \mathrm{C}$, due to the above-mentioned volatile fraction cracking reactions;

- The obtained pyrolytic oil could not be an adequate substitution for commercial diesel without pre-treatment, due to the high fuel quality standards imposed by modern IC engines and increasingly stringent environmental directives. On the other hand, low viscosity and sulfur content make pyrolytic oil an excellent fuel for industrial furnaces and boilers, whether used as pure fuel or mixed with fuel oil.

Author Contributions: Conceptualization, Z.Č., V.M., S.Đ.; methodology, M.M., M.S.; formal analysis, Z.Č., V.M., S.Đ.; investigation, M.M., M.S.; resources, B.S., M.I.M.; writing-original draft preparation, Z.Č., M.S., V.M.; visualization, B.S., M.I.M.; supervision, S.Đ., M.M. All authors have read and agreed to the published version of the manuscript.

Funding: This research received no external funding.

Institutional Review Board Statement: Not applicable.

Informed Consent Statement: Not applicable.

Data Availability Statement: All data are presented in the paper (manuscript).

Acknowledgments: This paper has been supported by the Ministry of Education, Science and Technological Development through the projects no. 451-03-68/2020-14/200156. The authors declare no competing interests.

Conflicts of Interest: The authors declare no conflict of interest. 


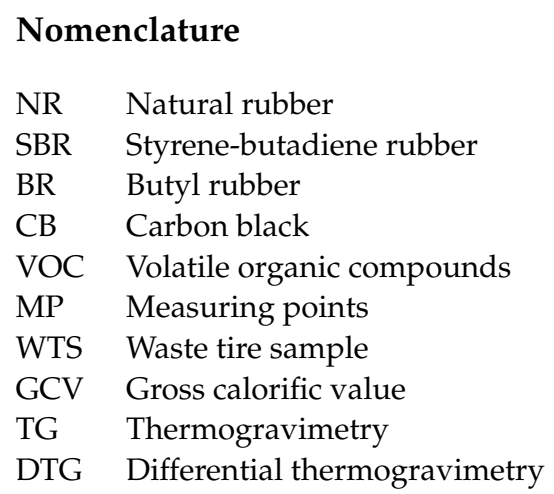

\section{References}

1. Jahirul, M.I.; Hossain, F.M.; Rasul, M.G.; Chowdhury, A.A. A Review on the Thermochemical Recycling of Waste Tyres to Oil for Automobile Engine Application. Energies 2021, 14, 3837. [CrossRef]

2. Liu, L.; Cai, G.; Zhang, J.; Liu, X.; Liu, K. Evaluation of Engineering Properties and Environmental Effect of Recycled Waste Tire-Sand/Soil in Geotechnical Engineering: A Compressive Review. Renew. Sustain. Energy Rev. 2020, 126, 109831. [CrossRef]

3. Rácz, L.; Solti, S.; Gresits, I.; Tölgyesi, S.; Benedek, D.; Valentínyi, N.; Mizsey, P. Measurement of Rarely Investigated Trace Elements As, $\mathrm{P}, \mathrm{Sr}, \mathrm{Zr}, \mathrm{Rb}$ and $\mathrm{Y}$ in Waste Tires. Period. Polytech. Chem. Eng. 2016, 60, 78-84. [CrossRef]

4. Kumar Singh, R.; Ruj, B.; Jana, A.; Mondal, S.; Jana, B.; Kumar Sadhukhan, A.; Gupta, P. Pyrolysis of Three Different Categories of Automotive Tyre Wastes: Product Yield Analysis and Characterization. J. Anal. Appl. Pyrolysis 2018, 135, 379-389. [CrossRef]

5. Quek, A.; Balasubramanian, R. Mathematical Modeling of Rubber Tire Pyrolysis. J. Anal. Appl. Pyrolysis 2012, 95, 1-13. [CrossRef]

6. Martínez, J.D.; Puy, N.; Murillo, R.; García, T.; Navarro, M.V.; Mastral, A.M. Waste Tyre Pyrolysis-A Review. Renew. Sustain. Energy Rev. 2013, 23, 179-213. [CrossRef]

7. Qu, B.; Li, A.; Qu, Y.; Wang, T.; Zhang, Y.; Wang, X.; Gao, Y.; Fu, W.; Ji, G. Kinetic Analysis of Waste Tire Pyrolysis with Metal Oxide and Zeolitic Catalysts. J. Anal. Appl. Pyrolysis 2020, 152, 104949. [CrossRef]

8. Labaki, M.; Jeguirim, M. Thermochemical Conversion of Waste Tyres-A Review. Environ. Sci. Pollut. Res. 2017, 24, 9962-9992. [CrossRef] [PubMed]

9. Wang, Z.; Burra, K.G.; Zhang, M.; Li, X.; Policella, M.; Lei, T.; Gupta, A.K. Co-Pyrolysis of Waste Tire and Pine Bark for Syngas and Char Production. Fuel 2020, 274, 117878. [CrossRef]

10. Aylón, E.; Fernández-Colino, A.; Murillo, R.; Navarro, M.V.; García, T.; Mastral, A.M. Valorisation of Waste Tyre by Pyrolysis in a Moving Bed Reactor. Waste Manag. 2010, 7, 1220-1224. [CrossRef]

11. Rodriguez, I.M.; Laresgoiti, M.F.; Cabrero, M.A.; Torres, A.; Chomon, M.J.; Caballero, B. Pyrolysis of Scrap Tyres. Fuel Process. Technol. 2001, 72, 9-22. [CrossRef]

12. González, J.F.; Encinar, J.M.; Canito, J.L.; Rodriguez, J.J. Pyrolysis of Automobile Tyre Waste. Influence of Operating Variables and Kinetics Study. J. Anal. Appl. Pyrolysis 2001, 58, 667-683. [CrossRef]

13. Murillo, R.; Aylón, E.; Navarro, M.V.; Callen, M.S.; Aranda, A.; Mastral, A.M. The Application of Thermal Processes to Valorise Waste Tyre. Fuel Process. Technol. 2006, 87, 143-147. [CrossRef]

14. Díez, C.; Martínez, O.; Calvo, L.F.; Cara, J.; Morán, A. Pyrolysis of Tyres. Influence of the Final Temperature of the Process on Emissions and the Calorific Value of the Products Recovered. Waste Manag. 2004, 24, 463-469. [CrossRef]

15. Aylón, E.; Callén, M.S.; López, J.M.; Mastral, A.M.; Murillo, R.; Navarro, M.V.; Stelmach, S. Assessment of Tire Devolatilization Kinetics. J. Anal. Appl. Pyrolysis 2005, 74, 259-264. [CrossRef]

16. Ucar, S.; Karagoz, S.; Ozkan, A.R.; Yanik, J. Evaluation of Two Different Scrap Tires as Hydrocarbon Source by Pyrolysis. Fuel 2005, 84, 1884-1892. [CrossRef]

17. Berrueco, C.; Esperanza, E.; Mastral, F.J.; Ceamanos, J.; Garcia-Bacaicoa, P. Pyrolysis of Waste Tyres in an Atmospheric Static-Bed Batch Reactor: Analysis of the Gases Obtained. J. Anal. Appl. Pyrolysis 2005, 74, 245-253. [CrossRef]

18. Laresgoiti, M.F.; de Marco Rodriguez, I.; Torres, A.; Caballero, B.; Cabrero, M.A.; Chomon, M.J. Chromatographic Analysis of the Gases Obtained in Tyre Pyrolysis. J. Anal. Appl. Pyrolysis 2000, 55, 43-54. [CrossRef]

19. Osayi, J.; Iyuke, S.; Daramola, M.; Osifo, P.; Van Der Walt, I.; Ogbeide, S. Evaluation of Pyrolytic Oil from Used Tires and Natural Rubber (Hevea brasiliensis). Chem. Eng. Commun. 2018, 205, 805-821. [CrossRef]

20. Rofiqul Islam, M.; Haniu, H.; Rafiqul Alam Beg, M. Liquid fuels and chemicals from pyrolysis of motorcycle tyre waste: Product yields, compositions and related properties. Fuel 2008, 87, 3112-3122. [CrossRef]

21. Barbooti, M.M.; Mohamed, T.J.; Hussain, A.A.; Abas, F.O. Optimization of Pyrolysis Conditions of Scrap Tires under Inert Gas Atmosphere. J. Anal. Appl. Pyrolysis 2004, 72, 165-170. [CrossRef]

22. Li, S.Q.; Yao, Q.; Chi, Y.; Yan, J.H.; Cen, K.F. Pilot-Scale Pyrolysis of Scrap Tires in a Continuous Rotary Kiln Reactor. Ind. Eng. Chem. Res. 2004, 43, 5133-5145. [CrossRef]

23. Đurić, S.; Kaluđerović, Ž.; Kosanić, T.; Ćeranić, M.; Milotić, M.; Brankov, S. Experimental Investigation of Pyrolysis Process of Agricultural Biomass Mixture. Period. Polytech. Chem. Eng. 2014, 58, 141-147. [CrossRef] 
24. Milotić, M. Investigation of the Influence of Process Parameters on the Pyrolysis and Gasification of Waste Automotive Tires. Ph.D. Thesis, University of Novi Sad, Novi Sad, Serbia, 2015. Available online: https://nardus.mpn.gov.rs/bitstream/id/42982/ Disertacija.pdf (accessed on 31 July 2021).

25. Kar, Y. Catalytic Pyrolysis of Car Tire Waste Using Expanded Perlite. Waste Manag. 2011, 31, 1772-1782. [CrossRef] [PubMed]

26. Rofiqul Islam, M.; Tushar, M.S.H.K.; Haniu, H. Production of Liquid Fuels and Chemicals from Pyrolysis of Bangladeshi Bicycle/Rickshaw Tire Wastes. J. Anal. Appl. Pyrolysis 2008, 82, 96-109. [CrossRef]

27. Maj, G. Emission Factors and Energy Properties of Agro and Forest Biomass in Aspect of Sustainability of Energy Sector. Energies 2018, 11, 1516. [CrossRef]

28. Dupuis, É.; Thiffault, E.; Barrette, J.; Adjallé, K.; Martineau, C. Bioenergy Conversion Potential of Decaying Hardwoods. Energies 2021, 14, 93. [CrossRef]

29. Król, K.; Nowak-Wózny, D. Application of the Mechanical and Pressure Drop Tests to Determine the Sintering Temperature of Coal and Biomass Ash. Energies 2021, 14, 1126. [CrossRef]

30. Williams, P.T.; Besler, S.; Taylor, D.T. The Pyrolysis of Scrap Automotive Tyres. The Influence of Temperature and Heating Rate on Product Composition. Fuel 1990, 69, 1474-1482. [CrossRef]

31. Wnorowska, J.; Ciukaj, S.; Kalisz, S. Thermogravimetric Analysis of Solid Biofuels with Additive under Air Atmosphere. Energies 2021, 14, 2257. [CrossRef]

32. Seidelt, S.; Muller-Hagedorn, M.; Bockhorn, H. Description of Tire Pyrolysis by Thermal Degradation Behaviour of Main Components. J. Anal. Appl. Pyrolysis 2006, 75, 11-18. [CrossRef]

33. López, F.A.; Centeno, T.A.; José Alguacil, F.; Lobato, B. Distillation of Granulated Scrap Tires in a Pilot Plant. J. Hazard. Mater. 2011, 190, 285-292. [CrossRef]

34. Lopez, G.; Olazar, M.; Amutio, M.; Aguado, R.; Bilbao, J. Influence of Tire Formulation on the Products of Continuous Pyrolysis in a Conical Spouted Bed Reactor. Energy Fuels 2009, 23, 5423-5431. [CrossRef]

35. Betancur, M.; Martínez, J.D.; Murillo, R. Production of Activated Carbon by Waste Tire Thermochemical Degradation with $\mathrm{CO}_{2}$. J. Hazard. Mater. 2009, 168, 882-887. [CrossRef]

36. Lehmann, C.M.B.; Rostam-Abadi, M.; Rood, M.J.; Sun, J. Reprocessing and reuse of waste tire rubber to solve air-quality related problems. Energy Fuel 1998, 12, 1095-1099. [CrossRef]

37. Pakdel, H.; Pantea, D.M.; Roy, C. Production of Dl-Limonene by Vacuum Pyrolysis of Used Tires. J. Anal. Appl. Pyrolysis 2001, 57, 91-107. [CrossRef]

38. Zhang, X.; Wang, T.; Ma, L.; Chang, J. Vacuum Pyrolysis of Waste Tires with Basic Additives. Waste Manag. 2008, 28, 2301-2310. [CrossRef]

39. Rowhani, A.; Rainey, T. Scrap Tyre Management Pathways and Their Use as a Fuel-A Review. Energies 2016, 9, 888. [CrossRef]

40. Leung, D.Y.C.; Yin, X.L.; Zhao, Z.L.; Xu, B.Y.; Chen, Y. Pyrolysis of Tire Powder: Influence of Operation Variables on the Composition and Yields of Gaseous Product. Fuel Process. Technol. 2002, 79, 141-155. [CrossRef]

41. Xu, J.; Yu, J.; He, W.; Huang, J.; Xu, J.; Li, G. Recovery of Carbon Black from Waste Tire in Continuous Commercial Rotary Kiln Pyrolysis Reactor. Sci. Total Environ. 2021, 772, 145507. [CrossRef] 